\title{
薬学新時代の大学院教育
}

平 澤 典保, ${ }^{*}, a$ 奥 直 人 $^{b}$

\section{Education of Graduate School of Pharmaceutical Sciences in New Generation: Introduction}

\author{
Noriyasu HIRASAWA ${ }^{*, a}$ and Naoto OKU ${ }^{b}$ \\ ${ }^{a}$ Graduate School of Pharmaceutical Sciences, Tohoku University, 6-3 Aoba, Aramaki, Aoba-ku, \\ Sendai 980-8578, Japan, and ${ }^{b}$ School of Pharmaceutical Sciences, University \\ of Shizuoka, 52-1 Yada, Suruga-ku, Shizuoka 422-8526, Japan
}

薬学教育改革により, 薬学部には 6 年制と 4 年制 が並立された。そして平成 22 年度は 4 年制を選択 した学生が大学院に進学する初めての年になった. この薬学教育改革により, 薬学・創薬研究に携わる 4 年制大学卒業後の大学院生が大幅に減少すること となった。一方, 将来の薬剂師の育成を担う指導者 の育成には 6 年制薬学部卒業後の大学院での教育も 必須であると考えられる.このような状況の現在, 大学院の教育はどうあるべきかを議論することは, 創薬研究者の育成並びに高度医療を担う薬剤師の育 成を含む今後の薬学の方向性を明確にする上で重要 であると考える．日本薬学会第 130 年会シンポジウ 厶「薬学新時代の大学院教育」では, 研究者及び薬 剤師を育成するそれぞれの立場から，そして行政の 立場から, 薬学における大学院教育に今何が求めら れているのか，そして何を目指し，どのような試み が始められているのか述べて頂いた。これにより新 時代における大学院教育の意義と大学院教育の目指 すべき姿について議論した，多くの聴衆を迎え，短 時間ながら大変有意義なシンポジウムになった。

富岡（東北大学）は 6 年制薬学部卒業後の 4 年制 大学院のプログラムとして, 高度医療を担う次世代 型専門薬剂師養成のための実践的臨床薬学教育シス テムを構築するために, 薬学研究科, 医学研究科, 大学病院の連携による試みを紹介した。 入村(東大)
はグローバル化と多領域融合をキーワードに，薬学 研究科の活動を紹介した。永井（岐阜薬科大学）は 公立単科大学における大学院教育の新しい方向性と して, 他の大学, 研究機関との連合大学院の設置が あり, 岐阜薬科大学での具体的な取り組みについて 紹介した。 大森（横浜薬大）は，自身の製薬企業で の経験をもとに, 創薬研究から大学院教育に望むこ ととして，製薬企業，ベンチャー企業，行政などを 取り込んだ薬系大学院を中核としたクラスター形成 を提唱した。奥（静岡県大）は日本薬学会の発展に おける 6 年制学部生, 大学院生への期待と問題点を 挙げた。吉田（文部科学省）は新たな薬学教育制度 における大学院の在り方に関する検討会での内容を 紹介し，今後の大学院設置における考え方を紹介し た.

本誌上シンポジウムでは, これらの発表の中で, 特に次世代型薬剤師教育としての大学院教育を目指 している富岡, 創薬研究を目指している大森, そし て, 行政面からの大学院の考え方について吉田の 3 人のシンポジウム内容を掲載することとした。現 在, 各大学では 6 年制大学の 4 年制大学院, 4 年制 大学の博士後期課程の設置に向け，それぞれ独自の カリキュラム構築を目指していると思われるが，本 シンポジウムがその参考になれば幸いである.

${ }^{a}$ 東北大学大学院薬学研究科（９980-8578 仙台市青葉 区荒巻字青葉 6-3), $b$ 静岡県立大学薬学部（４４228526 静岡市駿河区谷田 52-1)

*e-mail: hirasawa@mail.pharm.tohoku.ac.jp 日本薬学会第 130 年会シンポジウム S 24 序文 